\title{
The Effect of Human Capital, Social Capital, and Competency on the Empowerment of Bajo Ethnic Community in the Regency of Muna: A Gender Perspective
}

\author{
Hartina Batoa, La Rianda, Weka Widayati, Dasmin Sidu, Nur Rahmah, Putu Arimbawa \\ Department of Agribusiness, Halu Oleo University, Kendari, Indonesia \\ Email address: \\ ariembawa_kdi@yahoo.com (P. Arimbawa) \\ To cite this article: \\ Hartina Batoa, La Rianda, Weka Widayati, Dasmin Sidu, Nur Rahmah, Putu Arimbawa. The Effect of Human Capital, Social Capital, and \\ Competency on the Empowerment of Bajo Ethnic Community in the Regency of Muna: A Gender Perspective. Agriculture, Forestry and \\ Fisheries. Vol. 7, No. 1, 2018, pp. 6-10. doi: 10.11648/j.aff.20180701.12
}

Received: September 15, 2017; Accepted: October 14, 2017; Published: January 5, 2018

\begin{abstract}
A study was conducted to analyze the effect of human capital, social capital, and competency on the empowerment of Bajo ethnic from a gender perspective. The study site was Marobo, one of districts in the Regency of Muna. The district was purposely chosen because it had the highest number of Bajo people in that regency. Samples, a total of 88 households, were selected via simple random sampling. Data were analyzed with multiple regression analysis. The study showed that human capital, social capital, and competency directly affected the social and economic empowerment of Bajo people both the role of husbands and wives.
\end{abstract}

Keywords: Empowerment, Bajo People, Gender, Human Capital, Social Capital, Competency

\section{Introduction}

The ultimate goal of a community empowerment is to encourage citizens to improve their family's living standards and to optimize their resources [1]. Developing and empowering the Bajo community should be done for men and for women, as well. If it involves only men, this will create gender inequality [2]. Gender inequality will also affect the capacity development of women and men, particularly those related to their empowerment in doing their either domestic (household) or public activities. Gender issues arise from the lack of attention to the fact that the community as a development target consists of different segments, especially women and men [3].

According to Suyuti [4], Bajo women, in addition to having roles and responsibilities in family affairs, are also involved in the distribution and trade of fish catches and other fishery and marine products (e.g. seaweed). On the other hand, men go to the sea to fish to make a living besides practicing seaweed cultivation. As other societies, Bajo community also have potentials, in a form of human capital, social capital, competency and high spirit. They, however, are helpless and, therefore, need to be empowered in order for them not to be continuously stereotyped as the poor.
Muna Regency is one of the administrative areas in the Province of Southeast Sulawesi, Indonesia. Of the 33 districts in this regency, Bajo community are found in the District of Marobo and Maginti. The former has 734 households while the latter has 496 households of Bajo community [5].

Several community empowerment programs that have been conducted have yet to fully consider women roles. Instead, they have been in favor for men. Programs, such as training and being a board member in institutions or activities, have been intended for and attended by men only. Women believed to possess potentials, as well, have not been fully addressed in any Bajo community empowerment program. Bajo women's role is only in the domestic sector. although their actual activities can be more than just that. Based on the description, it was of importance to conduct a study to analyze the effect of human capital, social capital, and competency on the empowerment of Bajo ethnic from a gender perspective.

\section{Methods}

The current study belongs to descriptive or explanatory research. The facts which were described included human capital (e.g. education, skill and health), social capital (e.g. 
culture, trust and social network), competency (e.g. technical competency, management and communication), and community empowerment (e.g. income sources, number of working family members, income, consumption, protection, and access to information), and correlation between variables. The study was conducted in the District of Marobo, Regency of Muna Regency, Southeast Sulawesi, Indonesia. The population of the study was all of the 734 Bajo families residing in the study site. The number of samples was determined by using Slovin equation in [6], as follows:

$$
\mathrm{n}=\frac{N}{1+N e^{2}}=\frac{734}{1+(734)(0,1)^{2}}=88
$$

where $\mathrm{n}=$ number of samples, $\mathrm{N}=$ number of population, and $\mathrm{e}=$ degree of error $(1 \%)$

The calculation resulted in 88 samples which were then chosen based on simple random sampling method.

The data were analyzed based on multiple regression analysis model, as follows,

$$
\mathrm{Y}=\mathrm{b}_{\mathrm{o}}+\mathrm{b}_{1} \mathrm{X}_{1}+\mathrm{b}_{2} \mathrm{X}_{2}+\mathrm{b}_{3} \mathrm{X}_{3}+\mathrm{e}
$$

where $\mathrm{Y}=$ degree of empowerment, $\mathrm{b}_{\mathrm{o}}=$ intercept, $\mathrm{X}_{1}=$ human capital, $\mathrm{X}_{2}=$ social capital, $\mathrm{X}_{3}=$ competency, $\mathrm{b}_{1} \ldots \mathrm{b}_{3}=$ coefficient of regression for corresponding independent variable $\mathrm{X}, \mathrm{e}=$ error

Furthermore, the effect of a factor on a latent variable as to whether it was a direct or indirect effect was determined based on the Path analysis method, as follows,

$$
\mathrm{r}_{\mathrm{ij}}=\mathrm{p}_{\mathrm{ij}}+\sum \mathrm{k} \mathrm{p} \mathrm{p}_{\mathrm{ik}} \mathrm{r}_{\mathrm{jk}}
$$

where $r=$ coefficient of correlation, $p=$ coefficient of path, $i$, $\mathrm{j}, \mathrm{k}=$ variable $\mathrm{i}, \mathrm{j}$, and $\mathrm{k}$

\section{Results and Discussions}

\subsection{Social Capital on Social Empowerment and Economy of Bajo Community}

Social and economic empowerment of the community is the main goal of either national or regional development. In order to achieve such a community empowerment, all efforts are to be continually encouraged and implemented through government programs in all development sectors. [7] reported that social capital could affect family stability and community independence. The existence of relationships among individuals within an organization could improve their knowledge and access. [8] stated that social capital features of any social organization such as trust, norms and networks, could improve the efficiency of a society by facilitating all coordinated actions. This is in agreement with Putnam [7] that the social capital concept could be in a form of relationships or networks, beliefs, and norms that could be shared facilities that could be used by the society. Coleman [7] considered social capital as a resource because it could contribute to the individual and society prosperity as other resources such as nature, economy and human resources.
In the current study, 3 factors were found affecting socioeconomic empowerment of Bajo society, namely (i) competency proxied with business plan, business capital, marketing ability, fishing technique, fishing site, and fishing tool; (ii) social capital projected with belief in himself and others, belief in norms and social networks; and (iii) human capital proxied by the perception of education and fish processing. Factors affecting socio-economic empowerment of Bajo people are called exogenous variables, while the social and economic empowerment of Bajo society as dependent variables are called endogenous variables.

\subsection{The Effect of Human Capital, Social Capital and Competency on Bajo Community Empowerment}

\subsubsection{The Exogenous Variable $\left(X_{i}\right)$ Correlation on the Endogenous Variables or Social Empowerment $\left(Y_{1}\right)$}

Exogenous variables such as competency, social capital, and human capital are variables that can affect social empowerment. Our analysis indicates that human capital $\left(\mathrm{X}_{1}\right)$, social capital $\left(\mathrm{X}_{2}\right)$ and competency $\left(\mathrm{X}_{3}\right)$ directly affected social empowerment $\left(\mathrm{Y}_{1}\right)$ of bajo society. The effect of human capital on the social empowerment of Bajo society was because of their knowledge was better and their fish processing was improved as well, for instant by the use of modern equipment to meet the market demands. [9] considered human capital a channel for long-term economic growth. Improved knowledge and community access could indirectly contribute to a better community social welfare. With good knowledge and access, the community would be more innovative and more adaptive on their business to meet market demands. This is in accordance with [10] that a community having improved knowledge and access to resources would be able to make themselves out of poverty. Similarly, the effect of social capital on social empowerment proxied against consumption patterns and social interactions is caused by the belief in himself and others, and belief in norms and networks. This circumstance is in accordance with [11] that from gender perspective, social capital is a social variable that can determine social welfare. An improved access in a genderbased innovation in developing a business is the basic capital in improving competitions efficiency as witnessed nowadays. An improvement in welfare through gender-based social empowerment framed within social capital (e.g. trust, norms and networks) is the main determinant to accelerate community self-reliance both economically and socially. If a bond has occurred in a community, social capital will also be formed in such a way that its impact will be beneficial for the community's social empowerment Bourdieu in [12].

Table 1. Coefficient values in testing exogenous variables $\left(X_{i}\right)$ on social empowerment $\left(Y_{1}\right)$.

\begin{tabular}{lll}
\hline Variables & Coefficients & Probability \\
\hline Constant & 0.605 & 0.049 \\
Human capital $\left(\mathrm{X}_{1}\right)$ & 0.094 & 0.015 \\
Social capital $\left(\mathrm{X}_{2}\right)$ & 0.457 & 0.000 \\
Competency $\left(\mathrm{X}_{3}\right)$ & 0.390 & 0.000 \\
Adjusted R Square $=0.633$ & & \\
Calculated-F Probability $=0.000$ & \\
\hline
\end{tabular}


Competency also affected the social empowerment of bajo society. This was because the community were better in business planning, business capital management, product marketing, fishing techniques, and fishing site selection. This indicates that the competency factor has an important role in the formation and strengthening of community social empowerment, business planning, and business capital management.

Competency in running a business plays an important role in the success of a business. A network describes tools which are used to reduce risks and costs, in addition to improving access to business ideas, knowledge and capital [13]. Competency is very important in a society to provide a power to face any challenge. It also plays a key role in various aspects of community's daily lives because of which people will be able to work together to accomplish their goals. The correlation coefficients of our analysis are also significant (sig. (2-tailed) $>0.005)$ indicating the coefficient data are normally distributed (i.e. $\mathrm{r}_{1}=65,80 \%, \mathrm{r}_{2}=49,61 \%$, and $\mathrm{r}_{3}=$ $39,22 \%)$. The model for path analysis is presented in Figure 1

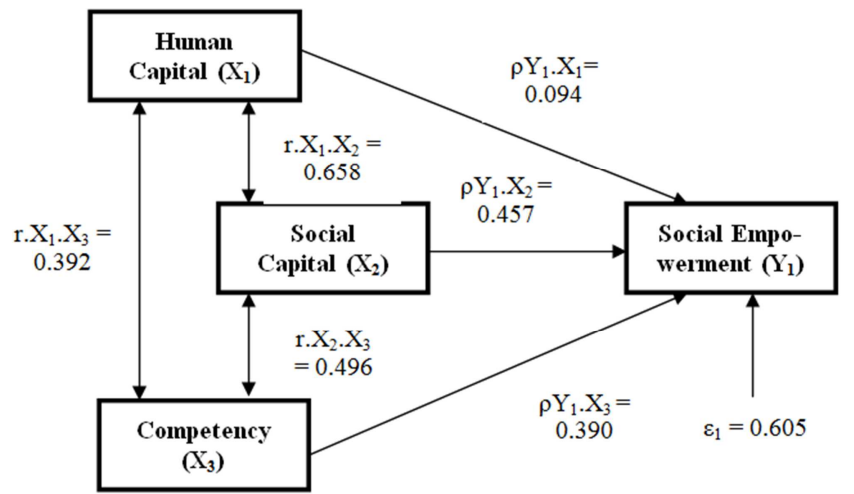

Figure 1. The Coefficients of Correlation for Exogenous Variables on Social Empowerment.
Mathematically, the regression equation for the first path analysis can be formulated, as follows,

$$
\mathrm{Y}_{1}=\rho_{1} \mathrm{X}_{1}+\rho_{2} \mathrm{X}_{2}+\rho_{3} \mathrm{X}_{3}+\varepsilon_{1}
$$

Social empower. $=\rho_{1}$ Human Capital $+\rho_{2}$ Social Capital + $\rho_{3}$ Competency $+\varepsilon_{1}$

Social empower. $=0.094 \mathrm{HC}+0.457 \mathrm{SC}+0.390 \mathrm{Com}+$ 0.605

The equation indicates the estimates of improved social empowerment. It can be interpreted that if there is a $1 \%$ increase from each exogenous variable occurs, there will be an increase in social empowerment value as much as the corresponding coefficient of exogenous variable.

\subsubsection{The Correlation Between Exogenous Variables $\left(X_{i}\right)$ and Social Empowerment $\left(Y_{1}\right)$ on Endogenous Variables or Economic Empowerment $\left(\mathrm{Y}_{2}\right)$}

Our analysis as to the effect of the exogenous and endogenous variable $\left(\mathrm{Y}_{1}\right)$ on endogenous variable $\left(\mathrm{Y}_{2}\right)$ shows that human capital $\left(\mathrm{X}_{1}\right)$, social capital $\left(\mathrm{X}_{2}\right)$ and competency $\left(\mathrm{X}_{3}\right)$ had an indirect significant effect while the social empowerment $\left(\mathrm{Y}_{1}\right)$ had a direct significant effect on endogenous variables (economic empowerment, $\mathrm{Y}_{2}$ ), as presented in Table 2 .

Table 2. Coefficient values in testing Exogenous Variables $\left(X_{i}\right)$ and Social Empowerment $\left(Y_{1}\right)$ on Economic Empowerment $\left(Y_{2}\right)$.

\begin{tabular}{lll}
\hline Variables & Coefficients & Probability \\
\hline Constant & 0.784 & 0.019 \\
Human capital $\left(\mathrm{X}_{1}\right)$ & 0.522 & 0.000 \\
Social capital $\left(\mathrm{X}_{2}\right)$ & 0.152 & 0.007 \\
Competency $\left(\mathrm{X}_{3}\right)$ & 0.031 & 0.027 \\
Social empowerment $\left(\mathrm{Y}_{1}\right)$ & 0.321 & 0.000 \\
Adjusted R Square $=0.384$ & & \\
Calculated F Probability $=0.000$ & \\
\hline
\end{tabular}

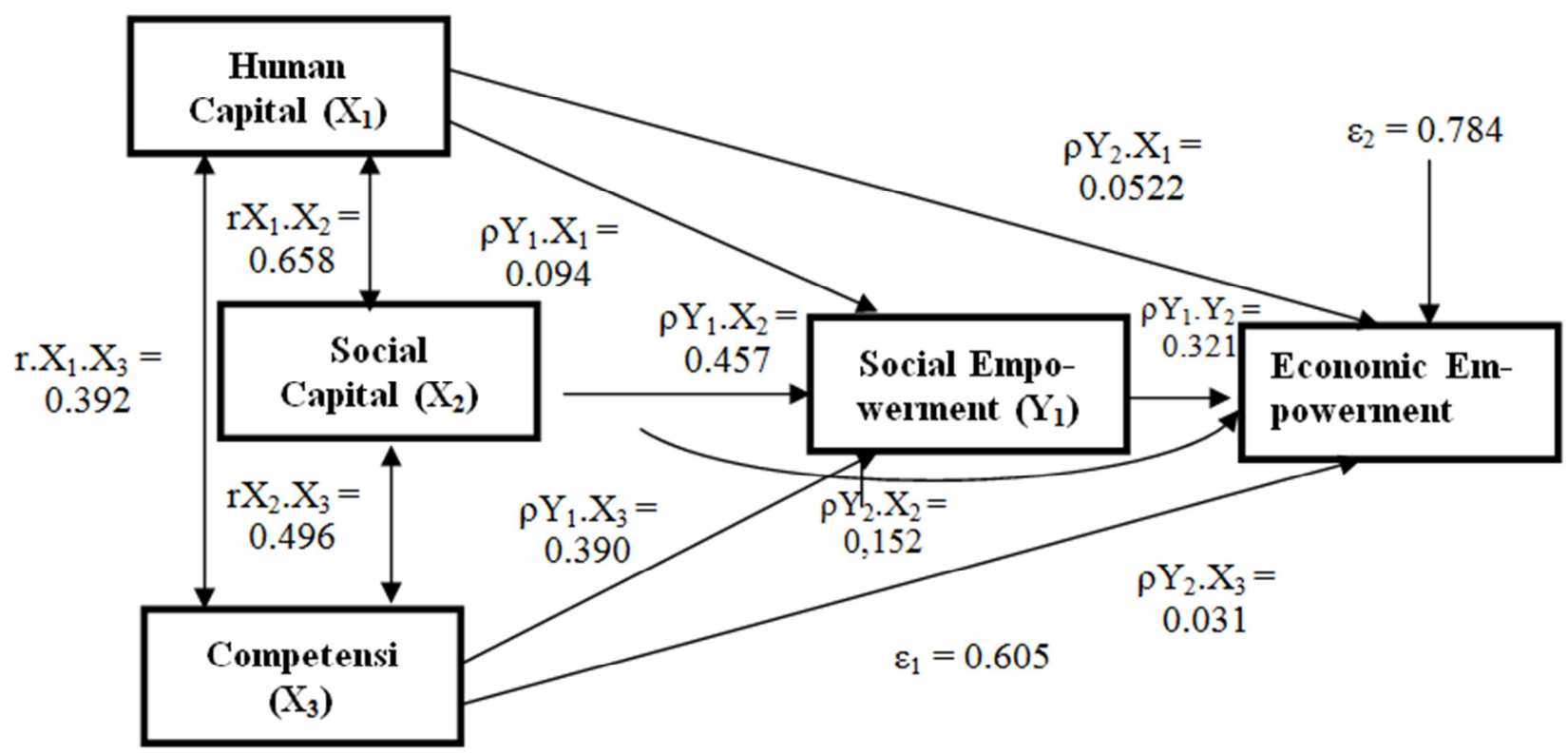

Figure 2. The Coefficients of Correlation for Exogenous Variables and $\left(Y_{1}\right)$ on the Economic Empowerment $\left(Y_{2}\right)$. 
The simultaneous and partial data analysis showed that all independent variables significantly affected the economic empowerment of Bajo society as indicated by the calculated $F$ value $(0.000)<$ degree of error (0.05). The effect was more because of a leverage factor, namely, an improvement in a social empowerment is a result of an improvement in human capital, social capital, and competency as the main motor in improving the socio-economic empowerment of Bajo society which in turn would had an implication on the society's selfsufficiency. [14] stated that social capital is an instrument in strengthening the emotional bond either in an organization or in a relationship among individuals based on beliefs, norms and networks. The analysis and partial testing on the second path analysis of each variable are presented in Figure 2.

Mathematically, the regression equation of the second path analysis can be formulated, as follows,

$$
\mathrm{Y}_{2}=\rho_{1} \mathrm{X}_{1}+\rho_{2} \mathrm{X}_{2}+\rho_{3} \mathrm{X}_{3}+\rho_{3} \mathrm{Y}_{1}+\varepsilon_{2}
$$

Economic Empower. $=\rho_{1} \mathrm{HC}+\rho_{2} \mathrm{SC}+\rho_{3} \mathrm{Comp}+\rho_{4} \mathrm{SE}+$ $\varepsilon_{1}$

Economic Empower. $=0.0522 \mathrm{HC}+0.152 \mathrm{SC}+$ 0.031 Comp. +0.321 SE.Sos +0.784

The equation indicates the estimates of improved social empowerment. It can be interpreted that if there is a $1 \%$ increase from each exogenous variable and social empowerment occurs, there will be an increase in economic empowerment value as much as the corresponding coefficient of exogenous variable and social empowerment.

\subsubsection{The Correlation of Exogenous Variables $\left(X_{i}\right)$ to Endogenous Variables or Social Empowerment $\left(Y_{1}\right)$ and Economic Empowerment $\left(\mathrm{Y}_{2}\right)$ from a Gender Perspective}

From the gender perspective, human capital of husbands and wives is important to determine the social empowerment of Bajo community. However, our analysis showed that the role of human capital in that community social empowerment was dominated by that of the husbands. This can be seen from the coefficient regression that the effects of human capital for the husbands on the social empowerment were all highly significant. The less dominant role of wives compared to that of husband was because of wives' lack of educations and health in that community.

The social capital owned by the Bajo people was very influential on their social empowerment. This could be seen from the significant effect when the role was played by either husbands or wives. In this social capital, the role played by either the husbands or wives less well was that in a form of reciprocity that did not significantly affect their social empowerment.

In the competency aspect, in doing business planning and business capital management, both husbands and wives highly significantly affected social empowerment. However, in other aspects of competency, there was no significant effect on social empowerment was found.

The correlation between independent variables and social empowerment on the economic empowerment was determined not only by human capital, social capital, and competency but also by the community's social empowerment. According to [15] social capital is a set of resources inherent to the relationship in a family and in a social organization and is useful for cognitive development which contribute to the improvement of the social and economic empowerment of the community. It can be seen that both husband's and wife's social interaction played a key role in their community economic empowerment. Similarly, to improve the community's economic empowerment was highly determined by the ability in planning a business and in managing business capital.

\section{Conclusions}

Based on our analysis, it can be concluded that human capital, social capital and competency directly had a direct significant effect on the social and economic empowerment of Bajo community. The significant effect of human capital, social capital and competency on Bajo community empowerment can be seen from the community's improved knowledge in fish processing where modern equipment had been used in order to meet market demands. It can also be seen from the existence of belief in norms and networks, and their ability in business planning, business capital management, product marketing, and fishing techniques and fishing site selection. Based on the gender perspective, husbands and wives played a key role in improving the social and economic empowerment of the Bajo community.

\section{Acknowledgements}

The authors would like to thank the Directorate General of Research and Higher Education of the Republic of Indonesia for funding the study through a research grant for Doctoral Dissertation in 2017. We would also like to thank the Head of Research Unit of the University of Halu Oleo for making this collaboration possible.

\section{References}

[1] Sumodiningrat, G. 2000. Visi dan Misi Pembangunan Pertanian Berbasis Pemberdayaan. IDEA. Yogyakarta.

[2] Kalyanamitra. 2010. Kesetaraan Gender. Yayasan Kalyanamitra. Pusat Komunikasi dan Informasi Perempuan. Jakarta.

[3] KPP dan PA RI. 2010. Materi Pokok Penyadaran Gender. Kementerian Pemberdayaan Perempuan Republik Indonesia. Jakarta.

[4] Suyuti, N. 2011. Orang Bajo Ditengah Perubahan. Penerbit Ombak. Yogyakarta.

[5] Badan Pusat Statistik Kabupaten Muna. 2014. Kabupaten Muna dalam Angka 2014. Raha. 
[6] Rianse, U dan Abdi. 2008. Metodologi Penelitian Sosial dan Ekonomi (Teori dan Aplikasi). Alvaberta. Bandung.

[7] Winter, I. 2000. Towards a Theorised Understanding of Family Life and Social Capital. Working Paper No. 21, April. Australian Institute of Family Studies.

[8] Putnam, R. D. 1993. The prosperous community: Social capital and public life. American Prospect 13: 35-42.

[9] Omodadepo, A. O and O. P. Akanni. 2013. Oil Wealth; Meat in Norway, Poison in Nigeria: An Analysis of Human Capital as a Transmission Channel of Resource Curse. Journal of World Economic Research. Volume 2, Issue 3, June 2013, Pages: $39-44$.

[10] Muafi. 2014. Green IT Empowerment, Social Capital, Creativity and Innovation: A Case Study of Creative City, Bantul, Yogyakarta, Indonesia. Journal of Industrial Engineering and Management http://dx.doi.org/10.3926/jiem.1341.
[11] Freeman, J. \& Garces-Bascal, R. M. 2015, Gender differences in gifted children, in M. Neihart, S. I. Pfeiffer \& T. L. Cross (Eds.) The Social and Emotional Development of Gifted Children.

[12] Thompson, M. 2015 Social Capital Innovation and Economic Growth. Documentos the Trabalho Working Paper Series. NIPE WP 3/2015.

[13] Bowles, S. and H. Gintis. 2002. Social capital and community governance. Economic Journal 112: 419-436.

[14] Lianga, Q., Z. Huangb, H. Luc and X. Wangd. 2015. Social Capital, Member Participation, and Cooperative Performance: Evidence from China's Zhejiang. International Food and Agribusiness Management Association (IFAMA), Vol. 18 Issue I.

[15] Babaei, H., S. S. Gill and N. Ahmad. 2012. Bonding, Bridging and Linking Social Capital and Psychological Empowerment among Squatter Settlements in Tehran, Iran. Journal of Basic and Applied Scientific Research (JBASR), 2(2): 109-115. 